\title{
Perbandingan Diagnosis Systemic Lupus Erythematosus Menggunakan Kriteria American College of Rheumatologi dan Systemic Lupus International Collaborating Clinics
}

Karuniawaty TP, Sumadiono, Cahya Dewi Satria

Bagian Ilmu Kesehatan Anak, Fakultas Kedokteran Universitas Gadjah Mada RSUP Dr. Sardjito, Yogyakarta

Latar belakang. Systemic lupus erythematosus (SLE) merupakan penyakit autoimun yang melibatkan multi organ dengan spektrum klinis dan imunologis yang luas. Kriteria diagnostik SLE pertama kali diperkenalkan oleh American College of Rheumatology (ACR) pada 1971 dan telah mengalami revisi pada 1982 dan 1997.

Tujuan. Membandingkan kriteria ACR dan kriteria SLICC dan menilai agreement antara kriteria SLICC dan ACR untuk menegakkan diagnosis SLE.

Metode. Penelitian studi cross-sectional terhadap pasien SLE yang dirawat di bagian Anak RS Sardjito Yogyakarta antara Januari 2009-Juni 2015. Metode total sampling digunakan pada penelitian ini. Pengumpulan data dilakukan melalui rekam medis, untuk menilai masing-masing kriteria pada saat anak terdiagnosis SLE, kemudian dilakukan penilaian agreement di antara kedua kriteria tersebut.

Hasil. Didapatkan 64 anak didiagnosis SLE dan 46 (71,9\%) memenuhi kriteria ACR. Sebanyak 39 (60,9\%) memenuhi kriteria SLICC. Penelitian ini mendapatkan overall agreement yang baik $(\rho 0=0,70)$ di antara kedua kriteria tersebut, dengan chance-corrected agreement $\kappa=0,33$, atau dinyatakan cukup.

Kesimpulan. Kriteria SLICC memiliki agreement yang cukup baik dengan kriteria ACR. Kriteria SLICC dapat dipertimbangkan sebagai alternatif metode untuk menegakkan diagnosis SLE pada anak. Perlu penelitian lanjutan untuk menilai kemungkinan penerapan kriteria ini untuk menggantikan kriteria ACR yang telah dipakai secara luas sebelumnya. Sari Pediatri 2016;18(4):299-303

Kata kunci: systemic lupus erythematosus, anak, diagnosis, kriteria

\section{Compare The Performance of American College Of Rheumatologi and Systemic Lupus International Collaborating Clinics}

Karuniawaty TP, Sumadiono, Cahya Dewi Satria

Background. Systemic Lupus Erythematosus (SLE) is a multi-organ autoimmune disease with clinical and serological heterogeneity. The most widely used diagnostic criteria for SLE are those proposed by the American College of Rheumatology in 1971 and have been revised twice in 1982 and 1997.

Objectives. To compare the performance of ACR and SLICC criteria and assess agreement between SLICC and ACR criteria for diagnosing SLE in children.

Methods. We performed a cross-sectional study on SLE patient at pediatric department Sardjito hospital in period from January 2009-Juni 2015. Total sampling was obtained. Data were collected to establish the ACR and SLICC criteria at the time patients were diagnosed. Agreement between those two diagnostic criterion was measured and agreement index including cohen $\kappa$ was calculated to infer accuracy of SLICC as diagnostic criteria for juvenile SLE.

Results. Among 64 juvenile SLE patients were identified, 46 (71,9\%) met ACR criteria and 39 (60,9\%) met SLICC criteria. There was good overall agreement $(\rho 0=0,70)$ but only fair chance- corrected agreement $(\kappa=0,33)$ that might be due to prevalence effect.

Conclusions. SLICC criteria have fair agreement with ACR criteria for diagnosing SLE in children. This study support that SLICC criteria can be used as alternative methods to diagnose SLE in pediatric patients, but possibility to replacement for the ACR criteria still need further research. Sari Pediatri 2016;18(4):299-303

Keywords: systemic lupus erythematous, childhood, diagnostic, criteria

Alamat korespondensi: Dr. Karuniawaty TP. Dr. Sumadiono, SpA(K). Bagian Ilmu Kesehatan Anak, Fakultas Kedokteran Universitas Gadjah Mada RSUP Dr. Sardjito, Yogyakarta. Email: tp.karuniawaty@gmail.com 
S ystemic Lupus Erithematosus (SLE) merupakan penyakit autoimun dengan spektrum bervariasi dan melibatkan berbagai organ. Penyakit ini merupakan sindrom klinis yang didasari disregulasi sistem imun dan ditandai oleh pembentukan auto-antibodi antinukleus (ANA), terutama anti dsDNA yang selanjutnya akan membentuk kompleks imun dan terjadi inflamasi serta kerusakan jaringan. ${ }^{1}$ Pada anak, insidens SLE mencapai 10-20 kasus per 100.000 anak dan umumnya lebih sering ditemukan pada anak perempuan di atas usia 10 tahun. Secara keseluruhan, gejala klinis pasien SLE, 15\%-17\% timbul pada umur di bawah 16 tahun dengan puncak insidens pada umur 10-14 tahunm sangat jarang muncul di bawah usia 4 tahun. Insidens pasti SLE pada anak sulit ditentukan, (missed-diagnosis). ${ }^{2}$

Klasifikasi SLE mengacu pada klasifikasi yang dibuat oleh American College of Rheumatology (ACR) pada tahun 1982 dan dimodifikasi pada tahun 1997. Kriteria diagnosis pada anak berdasarkan kriteria tersebut mempunyai sensitivitas 96\% dan spesifisitas 100\%. Diagnosis SLE ditegakkan apabila terdapat paling sedikit 4 dari 11 kriteria tersebut. Meskipun tujuan awal kriteria ini digunakan untuk mengklasifikasikan penyakit, tetapi kemudian kriteria ini berkembang luas sebagai kriteria diagnostik pada berbagai situasi klinik. Sejak itu, kriteria ACR mengalami revisi (pada tahun 1982 dan 1997). Berdasarkan kriteria ACR, manifestasi klinis pasien SLE, antara lain, lesi kulit, arthritis, gangguan ginjal, kelainan neurologis, perubahan hematologis dan semua yang masuk dalam kriteria tersebut. Antibody anti-nuclear serum, antibodi anti ds-DNA dan antibodi anti-Sm merupakan biomarker yang penting untuk penegakkan diagnosis SLE berdasarkan kriteria ACR. ${ }^{3-5}$ Kriteria klasifikasi ACR pada pasien anak memiliki banyak kelemahan. Kriteria ini telah banyak dikembangkan dan divalidasi pada pasien dewasa, tetapi tidak demikian pada populasi anak. The Systemic Lupus Collaborating Clinics mengajukan kriteria SLICC untuk SLE berdasarkan pemahaman terbaru mengenai autoantibodi dan pentingnya peran komplemen. Dalam kriteria SLICC, biomarker memegang peran penting dan berguna untuk membedakan SLE dari penyakit lainnya dan untuk keperluan monitoring aktivitas penyakit. Pada tahun 2012, Petri dan Magder mempublikasikan validasi kriteria SLICC untuk klasifikasi SLE. Berdasarkan kriteria SLICC, pasien harus memenuhi sekurangnya 4 dari 17 kriteria, termasuk sekurangnya terdapat satu kriteria klinis dan satu kriteria imunologis. ${ }^{3,4}$

Kriteria SLICC dibandingkan dengan kriteria ACR mempunyai sensitivitas lebih tinggi dan spesifisitas yang setara. Dengan demikian, diharapkan kriteria SLICC dapat digunakan sebagai kriteria diagnosis yang lebih baik dibandingkan kriteria yang dipakai sebelumnya untuk mengidentifikasi pasien anak dengan SLE. ${ }^{3}$

Penelitian ini bertujuan membandingkan kriteria ACR dan kriteria SLICC dalam menegakkan diagnosis SLE pada anak dan menilai kesepakatan (agreement) di antara kedua kriteria tersebut.

\section{Metode}

Penelitian cross sectional dengan subyek penelitian seluruh pasien SLE yang dirawat di RSUP dr. Sardjito mulai 1 Januari 2009 - 30 Juni 2015. Kriteria inklusi adalah anak usia 1-18 tahun dan tersedia rekam medis perawatan yang lengkap sejak mulai terdiagnosis. Sampel diperoleh dengan cara total sampling sehingga seluruh sampel yang ada diikutkan dalam penelitian ini.

Data dikumpulkan secara retrospektif dengan melakukan penelusuran rekam medik menggunakan kuesioner dan registri SLE dari UKK Alergi Imunologi IDAI. Selanjutnya, data diesktraksi dan masing-masing dinilai berdasarkan kriteria ACR dan SLICC oleh dua orang peneliti, bila terdapat ketidaksesuaian di antara keduanya maka dilakukan diskusi dengan ahli alergi imunologi anak.

Selanjutnya dilakukan pengolahan data dengan program pengolah data SPSS versi 20.0. Data diolah dan ditampilkan dalam grafik dan tabel deskriptif, kemudian dituangkan dalam tabel $2 \times 2$ untuk dilakukan penghitungan kesepakatan (index of agreement) antara kedua kriteria diagnosis.

\section{Hasil}

Didapatkan 72 pasien anak dengan SLE yang dirawat di RSUP dr Sardjito pada 1 Januari 2009-30 Juni 2015 memenuhi kriteria inklusi. Delapan data pasien tidak lengkap sehingga subyek penelitian yang diikutsertakan menjadi 64 orang.

Karakteristik subyek penelitian menunjukkan sebagian besar pasien SLE anak berjenis kelamin perempuan $(83 \%)$, dengan rentang usia terbanyak pada 11-15 tahun (48,5\%). 
Tabel 1. Karakteristik pasien anak dengan SLE

\begin{tabular}{ll}
\hline Karakteristik & $\mathrm{n}(\%)$ \\
\hline Jenis kelamin & $11(17)$ \\
Laki-laki & $53(83)$ \\
Perempuan & \\
Kelompok umur (tahun) & $1(1,6)$ \\
$1-5$ & $9(14,1)$ \\
$6-10$ & $31(48,4)$ \\
$11-15$ & $23(35,9)$ \\
$>15$ & \\
\hline
\end{tabular}

Manifestasi klinis pada kulit berdasarkan kriteria ACR dan SLICC cukup bervariasi. Fotosensitivitas (47,6\%) merupakan manifestasi klinis tersering pada temuan melalui kriteria ACR, sedangkan berdasarkan kriteria SLICC manifestasi kulit tersering berupa lupus kutaneus akut yaitu sebesar 47,5\% (Gambar 1). Kelainan ginjal berupa nefritis $(67,2 \%)$ merupakan manifestasi klinis tersering (Gambar 2).

Berdasarkan kriteria ACR dan SLICC temuan laboratorium menunjukkan leukopenia atau limfopenia merupakan profil hematologis tersering didapatkan pada pasien SLE anak. Profil imunologis pada pasien

Tabel 2. Analisis tabel $2 \times 2$

\begin{tabular}{|c|c|c|c|c|}
\hline \multirow[t]{2}{*}{ n (\%) } & & \multicolumn{2}{|c|}{ Kriteria SLICC } & \multirow[t]{2}{*}{ Jumlah } \\
\hline & & Terpenuhi & Tidak terpenuhi & \\
\hline \multicolumn{5}{|l|}{ Kriteria ACR } \\
\hline & Terpenuhi & $33(51,6)$ & $13(20,3)$ & $46(71,9)$ \\
\hline & Tidak terpenuhi & $6(9,4)$ & $12(18,7)$ & $18(28,1)$ \\
\hline Jumlah & & $39(61)$ & $25(39)$ & $64(100)$ \\
\hline \multicolumn{5}{|c|}{ Index of agreement } \\
\hline \multirow[t]{4}{*}{ Raw agreement } & & & \multicolumn{2}{|c|}{ Chance-corrected agreement } \\
\hline & Overall agreement & $\rho_{o}=70,3 \%$ & \multicolumn{2}{|c|}{$\kappa=0,34$ (fair) } \\
\hline & Positive agreement & $\rho_{\text {pos }}=40,4 \%$ & \multirow{2}{*}{\multicolumn{2}{|c|}{$\begin{array}{c}\mathrm{p}=0,005 \\
(\mathrm{JK} 95 \% \cdot 0.08-0.58)\end{array}$}} \\
\hline & Negative agreement & $\rho_{\text {neg }}=10,9 \%$ & & \\
\hline
\end{tabular}

Kriteria ACR

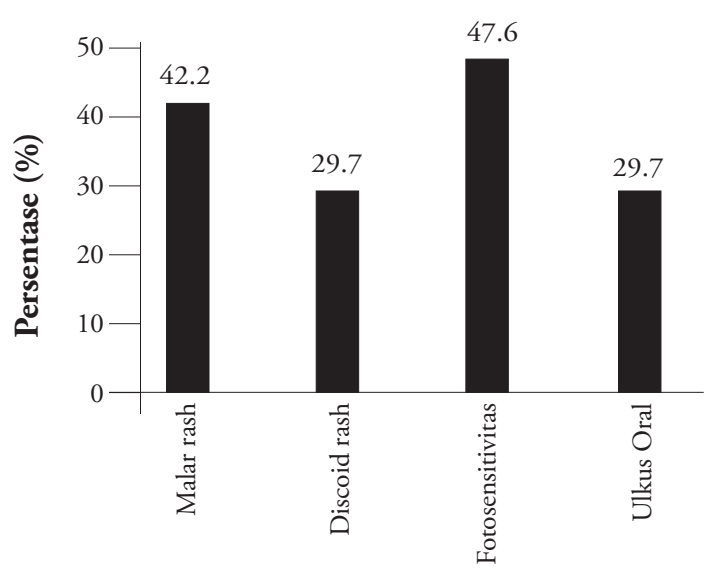

Kriteria SLICC

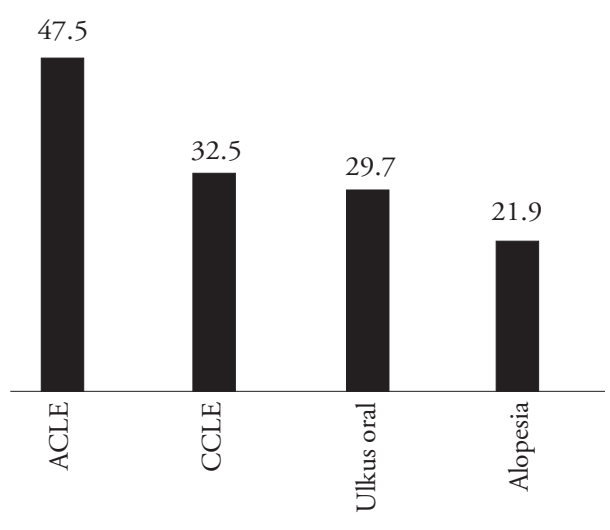

Gambar 1. Manifestasi kulit pasien anak dengan SLE 


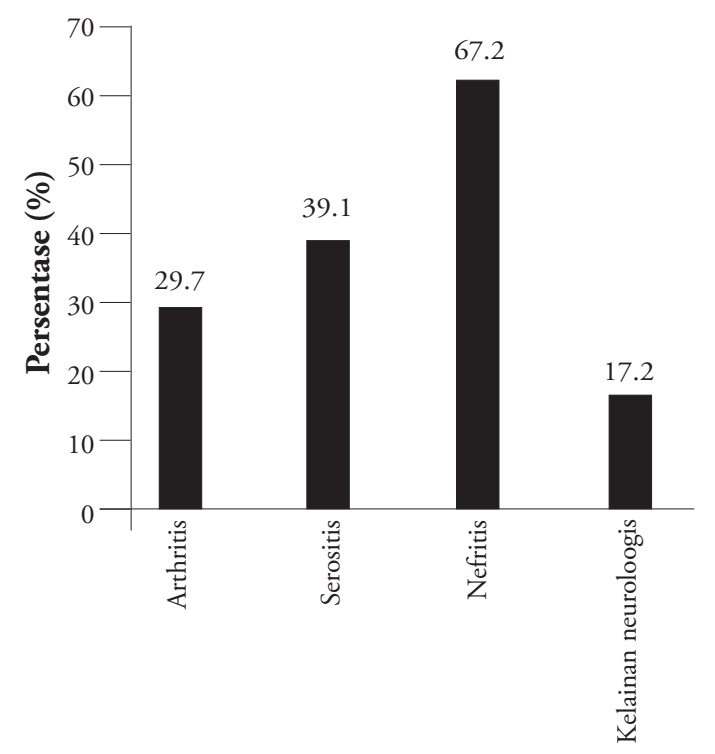

Gambar 2. Manifestasi klinis berdasarkan sistem organ secara bersama-sama. Overall agreement $(\rho 0=0,70)$, dengan chance-corrected agreement $\kappa=0,33$ (Tabel 2).

\section{Pembahasan}

Sebagian besar pasien SLE anak berjenis kelamin perempuan dengan rentang usia terbanyak pada 1115 tahun. Serupa dengan penelitian Kisaarlan ${ }^{6}$ yang melaporkan bahwa pasien SLE terbanyak adalah anak perempuan, dengan rerata umur $13 \pm 2,95$ tahun.

Manifestasi klinis pada kulit berdasarkan kriteria ACR, tersering adalah fotosensitivitas $(47,6 \%)$, sedangkan kriteria SLICC, tersering berupa lupus kutaneus akut $(47,5 \%)$. Hasil tersebut sedikit berbeda dengan penelitian Cerovec dkk pada sejumlah 110 pasien SLE anak di Kroasia yang melaporkan bahwa manifestasi kulit yang memenuhi kriteria ACR
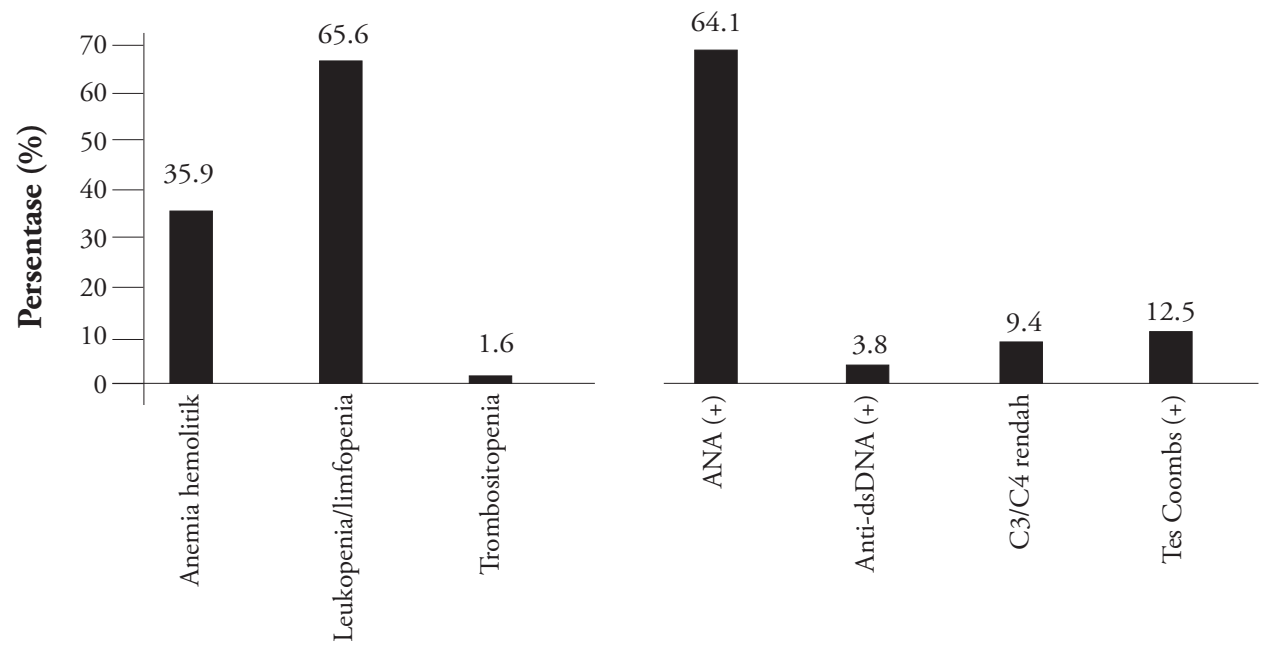

Gambar 3. Profil laboratoris dan imunologis

SLE menunjukkan tes ANA positif pada $64,1 \%$ kasus dan anti dsDNA positif ditemukan pada 3,8\% kasus, Parameter imunologis lainnya berupa pemeriksaan komplemen baik C3 atau C4 menunjukkan kadar yang rendah pada 9,4\% kasus, dan tes Coombs postif pada $12,5 \%$ pasien (Gambar 3).

Analisis tabel 2x2 menunjukkan 46 (71,9\%) subyek penelitian yang tegak diagnosis SLE berdasarkan kriteria ACR, sedangkan berdasarkan kriteria SLICC sebesar 39 (61\%). Sejumlah 33 (51,6\%) subyek penelitian terkonfirmasi diagnosis SLE berdasarkan kedua kriteria tersering berupa malar rash (52\%) dan yang memenuhi kriteria SLICC berupa lupus kutaneus akut (73\%). Manifestasi klinis berdasarkan sistem organ, kelainan ginjal berupa nefritis $(67,2 \%)$ merupakan manifestasi klinis tersering. Kisaarslan ${ }^{6}$ melaporkan temuan berbeda keterlibatan muskuloskeletal merupakan yang tersering muncul (54\%) diikuti kelainan ginjal (48\%).

Berdasarkan temuan laboratorium, kami mendapatkan leukopenia atau limfopenia merupakan profil hematologis tersering didapatkan pada pasien SLE 
anak, baik berdasarkan kriteria ACR maupun SLICC (65,6\%). Temuan serupa juga dilaporkan Ighe pada penelitiannya melalui Regional Swedish Systemic Lupus Register pada tahun 2014.

Berdasarkan tes ANA positif, kami menemukan 64,1\% kasus dan 3,8\% berdasarkan anti dsDNA. Parameter imunologis lainnya berupa pemeriksaan komplemen baik C3 atau C4 menunjukkan kadar yang rendah pada 9,4\% kasus, dan tes Coombs positif pada $12,5 \%$ pasien. Salah satu keterbatasan pada penelitian kami adalah tidak dapat melakukan pemeriksaan pada semua pasien, terutama terkait pembiayaan pemeriksaan. Penelitian di Swedia juga melaporkan profil imunologis tersering yang ditemukan berupa tes ANA positif pada $89,1 \%$ pasien, diikuti kadar komplemen rendah (14,5\%), tes Coombs positif (13,6\%), dan anti dsDNA positif (10,9\%).

Berdasarkan analisis tabel $2 \times 2$, terdapat $46(71,9 \%)$ subyek ditegakkan diagnosis SLE berdasarkan kriteria ACR, sedangkan berdasarkan kriteria SLICC 39 (61\%). Sementara subyek penelitian terkonfirmasi diagnosis SLE berdasarkan kedua kriteria secara bersama-sama adalah $33(51,6 \%)$. Terdapat $12(18,7 \%)$ subyek yang tidak terkonfirmasi dengan kriteria manapun, tetapi tetap diberikan terapi sesuai tata laksana SLE pada anak berdasarkan keputusan klinisi. Suatu penelitian kohort yang dilakukan Lloyd $\mathrm{dkk}^{9}$ mendapatkan 245 pasien SLE anak di Inggris, 78,4\% memenuhi kriteria ACR, sedangkan yang memenuhi kriteria SLICC 58,5\%. Penelitian kami mendapatkan overall agreement yang baik. Di antara kriteria ACR dan SLICC, chance-corrected agreement dinyatakan cukup (fair). Hasil tersebut sangat mungkin dipengaruhi oleh efek prevalensi.

\section{Kesimpulan}

Kriteria SLICC memiliki agreement yang cukup baik dibandingkan dengan kriteria ACR. Kriteria SLICC dapat dipertimbangkan sebagai alternatif metode untuk menegakkan diagnosis SLE pada anak. Perlu penelitian lanjutan untuk menilai kemungkinan penggunaan kriteria ini untuk menggantikan kriteria ACR yang telah dipakai secara luas sebelumnya.

\section{Daftar pustaka}

1. Fonseca AR, Gaspar-Elsas MIC, Land MGP, Oliviera SKF. Comparison between three system of classification criteria in juvenile systemic lupus erythematous. Rheumatology Adv Access 2014;14:279-36.

2. Petri M, Orbai A, Alarcon GS. Derivation and Validation of the Systemic Lupus International Collaborating Clinics Classification Criteria for Systemic Lupus Erythematosus. Arthritis \& Rheumatism 2012;64:2677-86.

3. Anic F, Zuvic-Butorac M, Stimac D, Novak S. New classification criteria for systematic lupus erythematosus correlate with disease activity. Croat Med J 2014;55:514-9.

4. Yu Cong, Gershwin ME, Chang C. Diagnostic criteria for systemic lupus erythematosus: A critical review. J Autoimmun 2014;48:10-3.

5. 5. McGhee JL, Kickingbird LM, Jarvis JN. Clinical utility of antinuclear antibody test in children. BMC Pediatrics 2004;4:13. doi:10.1186/1471-2431-4-13.

6. Kisaarslan AP, Sozeri B, Dusunsel R. The diagnosis of juvenile systemic lupus erythematosus with SLICC. Pediatr Rheum 2014;12:P32.doi:10.1186/1546-0096-12-S1-P322.

7. M, Anic B, Padjen I, Cikes N. Prevalence of the American College of Rheumatology classification criteria in a group of 162 systemic lupus erythematosus patients from Croatia. Croat Med J 2012;53:149-54.

8. Ighe A, Dahlström O, Skogh T, Sjöwall J. Application of the 2012 Systemic Lupus International Collaborating Clinics classification criteria to patients in a regional Swedish systemic lupus erythematosus register. Arthritis Research \& Therapy 2015;17:1-8.

9. Lloyd O, Heaf E, Morgan T, Roberts C, McCann L, Beresford MW. A comparison of the American college of rheumatology and the systemic lupus international collaborating clinics classification criteria for systemic lupus erythematosus using data from the UK juvenile systemic lupus erythematosus cohort study. Pediatr Rheum 2013;11:p346. 